\title{
ВИЗНАЧАЛЬНІ АСПЕКТИ ТРАСОЛОГІЧНӦ̈ ЕКСПЕРТИЗИ У ФОРМУВАННІ ДОКАЗОВОЇ БАЗИ ЩОДО НЕЗАКОННОЇ ПОРУБКИ ЛІСУ
}

\author{
КОПАНЧУК Володимир Олександрович - доктор наук 3 державного \\ управління, кандидат юридичних наук, доцент кафедри кримінального права та \\ процесу, Хмельницький університет управління та права імені Леоніда Юзькова \\ УДК 343.98.065
}

DOI 10.32782/NP.2021.3.11

\begin{abstract}
Излагаются правовъе основъг и перспективъ развития криминалистики в свете правовой ребормв в государстве. Рассмотренъ процессуально-правовъе и криминалистические вопросъ использования возможностей трасологии в вылялении, фиксаиии и исследовании доказательной базъ относительно незаконной порубки леса, а также обоснована необходимость эббективного сотрудничества работников следственных органов, прокуратурь, суда и криминалистов для качественного и объективного выполнения задач уголовного судопроизводства, и улучшения инновачионной политики Украинъл. Сбормированъ и приведенъ предложения по улучшению методики исследования следовой картинъ по уголовным правонарушениям против окружающей средьл. Раскрьвается значение и место этих новелл в системе права и криминалистики в цуелом. Сделанъ въводъ и данъ рекомендации по согласованному применению норм действующего законодательства в практической деятельности криминалиста и следователя. Привлечено внимание на необходимость дальнейшего научного сотрудничества ученъх, специалистов в области материального и процессуального права.

Ключевъе слова: уголовнъй прочесс, криминалистика, трасология, лес, незаконная порубка, правоохранительные органъ, досудебное расследование, уголовное производство, экспертиза, специалист.
\end{abstract}

\section{Постановка проблеми}

Внесок лісу та людей, які використовують його, у справу збереження та стійкого використання біологічного різноманіття, відродження планети Земля важко переоцінити. У вказаній статті буде здійснена спроба надати оцінку виконаній роботі щодо вирішення загальносвітових завдань та досягнення мети в галузі біологічного різноманіття лісів, наочно зобразити дієвість заходів політики, заходів та підходів як у плані збереження, так і в плані досягнення стійких результатів розвитку, а також окреслено шляхи боротьби із ганебним та кримінально караним діянням щодо «винищення зелених легень планети Земля» - незаконною порубкою лісу, що здійснюється та формується на підставі тематичних досліджень, інноваційних прийомів та взаємодії працівників правоохоронних органів, криміналістів та біологів, оскільки згідно $з$ доповіддю Організації Об”єднаних Націй «Стан лісів світу» від 22.05.2020 встановлено стрімке скорочення біологічного різноманіття планети та лісів зокрема [1].

Специфічність та унікальність розслідування кримінальних правопорушень проти довкілля вимагають від судових та правоохоронних органів, криміналістів розроблення нових методів щодо збирання доказової бази вчинення вказаних правопорушень та удосконалення вже чинних методів, норм кримінального та кримінального процесуального законодавства щодо боротьби із кримінальною протиправною поведінкою осіб-правопорушників щодо рослинного світу та лісу 


\section{Кримінальне право, кримінальний процес та криміналістика}

зокрема, 3 метою подальшого невід'ємного використання вказаних норм та методів у проведенні ефективного розслідування, збору доказової бази, у встановленні та притягненні винних осіб до відповідальності.

Це покладає особливу відповідальність на правоохоронні органи та криміналістів щодо проведення якісного та легітимного досудового розслідування у кримінальних провадженнях зазначеної категорії, повного та неупередженого збору доказової бази, що не уявляється можливим без суворого дотримання процедури законності. У цьому і полягає актуальність проблеми.

\section{Аналіз останніх досліджень та публікацій}

Проведений аналіз [1-8] показав, що вчені та практики неодноразово досліджували діяльність правоохоронних органів та криміналістів по збиранні доказової бази, проведенні слідчих дій у цілому та ії окремі аспекти зокрема. Проте розгляд визначальних аспектів трасологічної експертизи у формуванні доказової бази щодо незаконної порубки лісу вимагає детального дослідження та аналізу.

Мета статті - на підставі проведеного теоретичного аналізу та власного практичного досвіду розглянути визначальні аспекти трасологічної експертизи у формуванні доказової бази щодо незаконної порубки лісу, а також обгрунтувати необхідність ефективної співпраці працівників слідчих органів, прокуратури, суду, біологів та криміналістів для якісного та об'єктивного виконання завдань кримінального провадження та покращення інноваційної політики України взагалі.

\section{ВикАад основного матеріалу}

Аюдство 3 давніх пір вирубувало ліси, відвойовуючи землю для ведення сільського господарства та 3 метою отримання дров. Пізніше у людини виникла потреба у створенні інфраструктури (населених пунктів та шляхів сполучення між ними), а також у видобутку корисних копалин, що стало рушійною силою у збезлісенні територій. Проте головною причиною у винищенні лісів стало збільшення потреби у їжі, а саме: площ для випасання худоби та посів сільськогосподарських культур.

Якщо звернутися до звичайної логіки, то стане зрозумілим, що лісове господарство не в змозі виробляти стільки їжі, як і очищене від дерев угіддя. Окрім того, проаналізувавши специфіку тропічних та тайгових лісів стане зрозумілим, що вони практично не в стані підтримувати людське населення, оскільки їстівні ресурси є занадто розкиданими географічно. Це наводить на виправдувальний висновок про те, що природа не змогла 6 підтримати сучасний рівень населення та його рівень життя, якщо б людство не вдавалося до збезлісення.

Так, згідно з оцінюванням британського захисника довкіляя Нормана Маєрса, 5 \% збезлісення припадає на випас худоби, 19 \% відбувається через лісозаготівлю, $22 \%$ - внаслідок розширення плантацій олійної пальми, а $54 \%$ внаслідок підсічно-вогневого землеробства [2].

Необхідно зрозуміти та усвідомити, що головною складовою частиною природи є саме Nic.

入ic - це екологічна система, біогеоценоз, у якій головною життєвою формою є дерева [3].

При розгляді лісу як поняття ми можемо вказати, що це частина біосфери нашої планети (у величині Всесвіту) або ж це може бути насадженням дерев певного різновиду (у місцевому, локальному розумінні). Окрім того, ліс може виступати як природно-зональний підрозділ, як провінційний підрозділ або як лісовий масив чи екологічна система.

У відповідності до інформації всесвітньої мережі Інтернет ліси займають біля третини площі суходолу, площа лісу на планеті Земля складає 38 млн. кв. км., проте на початку XXI століття людина винищила біля 50 \% площі лісів, які раніше існували на нашій планеті [3].

Масова вирубка (інше техногенне та антропогенне винищування лісів) є головним фактором утворення на певних ділянках Землі збезлісення.

Так, збезлісення - це технічний процес перетворення земель, на яких перебуває ліс, у земельні ділянки (угіддя) без лісового покриву: поля, огородництва, сільгоспугіддя, пасовища, населені пункти та інш.

Головними причинами збезлісення можна виділити: 
- техногенне винищення лісу 3 метою перепризначення земельної ділянки під категорії: «сільськогосподарське угіддя» або «населений пункт»;

- винищення лісу без відновлення його у подальшому (т.б. без «лісооновлення»);

- природні причини: буревії, зміна клімату, акваторії озер, річок та джерел на певній території;

- антропогенні явища - як негативний фактор діяльності людини : забруднення території, кислотні дощі, лісові пожежі, причиною яких стало недбале ставлення людини, та інш.

Процес винищення лісу завжди був актуальною проблемою у багатьох частинах Землі, оскільки цей згубний процес винищує екологічні, кліматичні та соціально-економічні характеристики та, як наслідок, знижує якість життя.

Збезлісення $\varepsilon$ рушійним фактором до зниження біологічного різноманіття, запасів деревини (навіть для промислового використання), грунтової ерозії, що є причиною збільшення кількості ярів, вимивання родючого шару грунту, зниження водності річок. Окрім того збезлісення через виділення в атмосферу планети вуглецю у вигляді СО2, який перебуває у біомасі лісу, призводить до посилення парникового ефекту нашої планети.

Так, у відповідності до інформації Міжнародного Інституту світових ресурсів та Всесвітнього центру природоохоронного моніторингу, за останні 5 тисяч років людством була винищена майже половина лісів, які існували на планеті Земля, $75 \%$ знищених лісів припадає на ХX століття. $325 \%$ лісів, що залишились, складаються 3 природних екосистем, решта - сильно змінена під натиском людини [4].

3 урахуванням викладеного не дивно, що масова вирубка лісів постає проблемою, яка винесена в авангард міжнародної арени в останні десятиліття.

На жаль, ми стикнулись із прямо пропорційною складовою: при зростанні потреб людства - неминуче зростають масштаби вирубування лісів, що є негативним наслідком урбанізації. Це не тільки вирубування дерев та лісів 3 метою розширення сільського господарства, житлового будівництва, але і незаконна порубка або незаконне перевезення, зберігання, збут лісу, а також знищення або пошкодження об'єктів рослинного світу (зокрема лісових масивів). Незаконні дії зазначеного характеру законодавець України відніс до категорії кримінально караних діянь та відповідальність за них передбачив у статтях 245 та 246 Кримінального кодексу України [5].

Аналізуючи та встановлюючи важливість лісів, зазначимо, що:

- $\quad$ ліс забезпечує середовище існування для тварин та засоби для існування людей;

- ліс покриває 30 \% площі нашої планети;

- дерева лісу є важливим та невід'ємним компонентом екосистеми, поглинаючи вуглець (так, для прикладу, запас кисню у розмірі 20 \% виробляється в лісі річки Амазонка [6]);

- четверта частина ліків у світі виробляються з рослин лісу;

- $\quad$ ліс забезпечує захист водосховищ, запобігає ерозії грунту та пом'якшує зміни клімату.

Згідно 3 доповіддю ООН «Стан лісів світу» від 22.05.2020 щорічно в результаті розширення орних угідь та іншої діяльності людини 3 поверхні землі зникає 10 млн. гектарів лісів та лісонасаджень, що обертається стрімким скороченням біологічного різноманіття планети [1].

Автори доповіді відзначають, що за останні три десятиліття темпи збезлісення Землі сповільнилися, однак, незважаючи на це, з 1990 року було втрачено близько 420 млн. гектарів лісу. Саме на ліси припадає основна частина всього наземного біологічного різноманіття планети: 60 тисяч різних видів рослин і дерев, 80 відсотків всіх видів земноводних, 75 відсотків видів птахів і 68 відсотків видів ссавців. Зникнення лісів веде до зникнення багатьох диких видів флори та фауни.

3 урахуванням вищевикладеного неабиякою проблемою у збереженні лісового масиву будь-якої країни є боротьба із незаконною порубкою або незаконним перевезенням, зберіганням, збутом лісу, а також знищенням або пошкодженням об'єктів рослинного світу (зокрема лісових масивів).

3 метою припинення вказаної протиправної діяльності науковці, криміналісти-практики та правоохоронні органи розробили ряд методичних напрацювань для збору доказової бази на місці події, її опрацюванні та використанні для підтвердження винуватості особи у вчиненні вказаного ганебного явища 


\section{Кримінальне право, кримінальний процес та криміналістика}

- «протиправно-корисливого винищення зеленої планети».

На практиці дослідження слідів незаконної порубки лісу відбувається шляхом винесення слідчим суддею ухвали про призначення судово-трасологічної експертизи.

Проведення вказаної судової експертизи, як правило, доручається експерту, який має кваліфікацію судового експерта з правом проведення трасологічної експертизи за експертною спеціальністю 4.2 «Дослідження знарядь, агрегатів, інструментів і залишених ними слідів, ідентифікація цілого за частинами» Київ. 2015. Реєстраційний номер за реєстром методів судових експертиз 4.2.31 [7].

Зокрема, трасологія - це вчення про сліди кримінального правопорушення та порушника, є найважливішою галуззю сучасної криміналістичної техніки.

Вперше термін «трасологія» був використаний юристом, криміналістом, спеціалістом 3 тактики та організації розслідування злочинів, професором I.M. Якимовим для позначення вчення про сліди та речові докази у 1938 році [8, С.108].

Для проведення трасологічної експертизи з метою дослідження слідів незаконної порубки лісу направляються зрізи стовбурів зрізаних дерев, які, як правило, вилучаються працівниками правоохоронних органів в осіб, які можуть бути причетними до вчинення вказаного протиправного діяння, а також зрізи пнів дерев, місце розташування яких встановлено при огляді місця події або під час допиту фігурантів події.

Для зручності на практиці зрізи пнів позначаються графітним олівцем синього (або будь-якого іншого) кольору із зазначенням цифр та стовбури дерев певного виду, які також позначаються графітним олівцем певного кольору та літерами «3С» (т.б. зріз стовбурів) із зазначенням цифр від 1 до 10 (для прикладу).

На вирішення експертизи ставиться запитання:

- Чи були частинами одного цілого надані на дослідження зрізи пнів позначені графітним олівцем (синъого) кольору із зазначеними цифрами (від 6 до 23) та стовбурів дерев виду «ясен» позначені графітним олівцем (чорного) кольору літерами «ЗС», із зазначеними цифрами від 1 до 10?
При порівняльному дослідженні збіг може бути встановлено за наступними загальними та окремими ознаками:

- загальною формою, будовою та розмірами розрізу деревини, розташуванням та розмірами: внутрішньої гнилості, річних кілець та лінії розрізу;

- наявністю та формою ділянок кори, а також лініями розділення.

Виявлені експертом під час дослідження загальні та окремі ознаки, що збігаються у порівнювальних зрізах стовбурів та пнів, повинні бути стійкими, суттєвими, у своїй сукупності утворювати індивідуальний комплекс ознак, достатній для висновку про те, що зрізи пнів та зрізи стовбурів до розділення були частинами одного цілого.

У зв’язку із можливою відсутністю проміжних частин деревини із спільними поверхнями розділення та інших об'єднуючих ознак висновок про належність до частин одного цілого не може бути позитивним, а тому встановити, чи є зрізи пнів та зрізи стовбурів дерев частинами одного цілого, неможливо.

Таким чином, результати проведеного вище описаного криміналістичного дослідження може виступати підставою для висновку експерта про те, що зрізи пнів та зрізи стовбурів до розділення були частинами одного цілого (одного дерева), що є вагомою доказовою базою при зібранні та оцінці ознак протиправності діяння.

Як висновок до статті зазначимо, що, на нашу думку, специфічність та унікальність розслідування кримінальних правопорушень проти довкіля вимагають від судових та правоохоронних органів, криміналістів розроблення нових методів щодо збирання доказової бази вчинення вказаних правопорушень та удосконалення вже чинних методів щодо боротьби із кримінальною протиправною поведінкою осіб-правопорушників щодо рослинного світу та лісу зокрема, з метою подальшого невід'ємного використання вказаних напрацювань у проведенні ефективного розслідування, збору доказової бази, у встановленні та притягненні винних осіб до відповідальності.

Зважаючи на наявність недоліків у цій сфері процесуально-правової та криміналістичної діяльності, вважаємо за актуальні по- 


\section{АНОТАЦІЯ}

Викладаються правові основи та перспективи розвитку криміналістики у світлі правової реборми у державі. Розглянуто прочесуально-правові та криміналістичні питання щоодо використання можливостей трасологій у виявленні, фоксащї та дослідженні доказової бази щодо незаконної порубки лісу, а також обгрунтована необхідність ефективної співпраці працівників слідчих органів, прокуратури, суду та криміналістів для якісного та об’єктивного виконання завдань кримінального провадження, та покращення інновачійної політики України. Сбормовані та наведені пропозииіи щодо покращення методики дослідження слідової картини у кримінальних правопорушеннях проти довкілля. Розкривається значення та місие ици новел у системі права та криміналістики у иілому. Зроблені висновки та надані рекомендаиіи щодо узгодженого застосування норм чинного законодавства у практичній діяльності криміналіста та слідчого. Привернуто увагу на необхідність подальшої наукової співпраці вчених, спеціалістів у галузі матеріального та процесуального права.

Ключові слова: кримінальний прочес, криміналістика, трасологія, ліс, незаконна поруб-

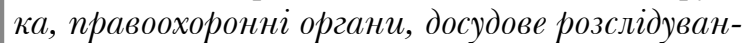
ня, кримінальне провадження, експертиза, спеціаліст.

дальші дослідження відповідної спрямованості, адже останні створюватимуть перспективи теоретичних та практичних напрацювань та сприятимуть розв'язанню проблемних питань на цьому напрямку.

\section{Аітература}

1. Доклад ООН "Состояние лесов мира (леса, биоразнообразие и люди)" 22.05.2020: ФАО и ЮНЕП. 2020 год. Состояние лесов мира - 2020. леса, биоразнообразие и люди. Рим, ФАО. [Електронний ресурс] : https://doi.org/10.4060/ са8642 (дата звернення: 23.06.2021).

2. Маєрс Н. Поклик життя. 2010 [Електронний pecypc]: https://ua.kinorium.com/name (дата звернення: 23.06.2021).

3. Вікіпедія. [Електронний ресурс]: https://ru.wikipedia.org/wiki (дата звернення: 23.06.2021).
4. Міністерство захисту довкілля та природних ресурсів України. Офіційний сайт. [Електронний ресурс]: https://mepr.gov.ua (дата звернення: 23.06.2021).

5. Кримінальний кодекс України. Відомості Верховної Ради України, 2001, № 25-26, ст.131. (редакція станом на 23.06.2021) [Електронний ресурс] : http://zakon.rada.gov.ua (дата звернення: 23.06.2021).

6. Діджиталізація ваших форм. Електронний pecypc «MorreApp» [Електронний ресурс]: https:// moreapp.com (дата звернення: 23.06.2021).

7. Міністерство юстиції України. Офіційний сайт. [Електронний ресурс]: https://minjust.gov. uа (дата звернення: 23.06.2021).

8. Криминалистика. Под ред.А.Н. Васильева. М., Изд-во Моск. ун-та, 1980. - 495 с.

\section{Kopanchuk V.A. \\ DEFINING ASPECTS OF THE TRACE EXAMINATION EXPERTISE IN THE FORMATION OF THE EVIDENCE BASE REGARDING ILLEGAL LOGGING}

The article contains the legal foundations and prospects for the development of forensic science in the light of legal reform in the state. The procedural, legal and forensic issues of using the capabilities of traceology in identifying, fixing and researching the evidence base regarding illegal logging are considered. Substantiated the need for effective cooperation between employees of investigative bodies, prosecutors, courts and criminalists for the quality and objective performance of the tasks of criminal proceedings, and improving the innovation policy of Ukraine. Proposals for improving the methodology for studying the trace picture of criminal offenses against the environment have been formulated and presented. The meaning and place of these short stories in the system of law and forensic science as a whole is revealed. The conclusions were drawn and recommendations were given on the coordinated application of the norms of the current legislation in the practical activities of the criminologist and the investigator. Attention is drawn to the need for further scientific cooperation of scientists, specialists in the field of substantive and procedural law.

Keywords: criminal procedure, forensics, traceology, forest, illegal felling, law enforcement agencies, pre-trial investigation, criminal proceedings, expertise, specialist. 